\title{
Developing Power and Influence for the Professional Teacher Librarian
}

\author{
Suzette Boyd \\ Head of Library and Information Services \\ Scotch College Library and Information Centre \\ Morrison Street \\ Hawthorn, Victoria 3122 \\ Australia \\ Suzette.Boyd@scotch.vic.edu.au
}

Are teacher-librarians in Australia influential in their school communities? Certainly, many are considered successful by other teacher-librarians. These are the ones with high professional profiles. They write widely in library journals, they speak at conferences and are highly regarded in the international school library community. They exert influence as teacher-librarians within their profession. Their innovations are taken up, their ideas are debated and their leadership may be inspirational. But what of their role within their own schools. How do the students, the teachers, their principals regard them?

Is the influence they experience within their profession, transferred to their wider school communities? Indeed, how do they regard themselves?

This paper will study the responses to a series of questions from six teacher-librarians who are generally regarded as influential leaders within their field. These responses will be analysed with a view to testing Hartzell's (1994) scaffolding for building influence for the teacher-librarian. The major limitation of the survey, is that only the teacher-librarians' responses and perceptions are under review. It was not possible to test the perceptions of those who work in the schools with the teacher-librarian respondents. So, Hartzell's fundamental principle of influence could not be tested.

"Influence is derived from the perceptions of the person to be influenced, not from the perceptions of the person doing the influencing. The key to building your influence lies in your ability to shape the perceptions of others" (Hartzell 1994:p.viii)

However, it is possible to compare and contrast the key components for building influence that Hartzell proposes, with those that are being practised in some of Australia's leading schools by some of our most high profile teacher-librarians.

How teacher-librarians see themselves is a significant starting point in testing their potential for power and influence. To be influential requires teacher-librarians to be visible and to engage with the people with whom they work - the students, the library staff, the teachers, the principal and the wider community. Hartzell (1994) maintains that without engagement, there is no recognition. Teacher-librarians need to build a power base of influence and then be prepared to maintain the influence that the power base will bring. We will see from the survey just how the respondents believe they engage with their community; their spheres of influence; their strategies for engagement; their involvement in politics and the building of influence through engagement of activities outside the library. 


\section{Surveying teacher-librarians}

The idea for this project began after reading Hartzell's text " Building Influence for the School Librarian". A comment and some questions were posted to the ETL 521 forum. It was suggested that despite the prevailing belief that the relationship the teacher-librarian has with the principal is paramount, there are other relationships (depending on the educational environment) which are also significant. The forum was asked to name other significant relationships, along with this question:

"Can you think of an occasion/incident when through your influence as a teacher-librarian, something changed, an innovation was introduced, or a problem was solved for the whole school community"

The variety of responses to these questions along with the interest and passion with which people responded, inspired the undertaking of a more detailed survey of selected teacher-librarians.

Six teacher-librarians were selected for the survey. Five of those selected are known personally. Advice was sought from James Henri as to his opinion of the suitability of the teacher-librarians selected. He advised the inclusion of the Western Australian participant. Three teach in boy's schools and three teach in girl's schools. Five of the six are from the independent system. One is from New South Wales, one is from Western Australia and the other four from Victoria. All are female.

They were first approached by e-mail, describing the project and inviting them to participate in the survey. None of them knew who else was being surveyed, only that they were six in number and were all considered to be successful and influential by the profession. They were given an estimation of the number of questions, the time the survey may take to complete and a time frame for completion. All but one of the responses was returned within the given time frame. All respondents had to be followed up for further information, as some of their answers were incomplete, or further clarification was required.

Questions ranged from personal questions about years of experience to questions about their perceptions of their influence, their strategies for achieving influence and their relationship with their principal. (See appendix 1 for survey)

\section{What does the survey tell us about the teacher-librarians?}

To ensure anonymity and confidentiality when analysing responses, the teacherlibrarians will be identified as A, B, C, D, E and F. Each of those surveyed had between 16 and 30 years experience as teacher-librarians, so there was a wealth of background experiences on which to build influence. It is worth noting that two of the respondents $\mathbf{D}$ and $\mathbf{F}$ have been in their schools under 2 years, $\mathbf{B}$ and $\mathbf{E}$ over 6 years and $\mathbf{A}$ and $\mathbf{C}$ over 18 years. Four of the six respondents worked in prestigious independent schools, the fifth worked in a small independent school and the sixth worked in a prestigious state school. (See appendix 2 for table of background data)

When asked if they knew their Myers Briggs personality type, only $\mathbf{C}$ and $\mathbf{F}$ responded. $\mathbf{C}$ indicated that library staff had been "given the opportunity" to undertake professional development, perhaps indicating a lack of focus on the attributes of influential people. Who are you? What is your preferred way of operating? What are the attributes of leaders? What is your personality type? How can you use the strengths of your personality 
type to build influence? On the other hand respondent $\mathbf{F}$ indicated that she had personally undertaken an MBTI workshop at her own expense and was "impressed with the insights that it gave me". She "decided to organise" an in-service for her library staff, so they could all have the opportunity to better understand their own and others preferred ways of operating.

The language used by the two respondents $\mathbf{C}$ and $\mathbf{F}$ seem to indicate that $\mathbf{F}$ is more proactive as she 'decided to organise', while $\mathbf{C}$ was 'given the opportunity'. It would appear that $\mathbf{F}$ does have some influence with the professional development people in her school, as she was able to provide a school-funded MBTI opportunity for her staff. In reviewing question 14 and 15 about the influences on respondents, we see that $\mathbf{F}$ has included the Director of Research and Development as both someone who influences her and someone she influences. On the other hand, in C's responses, a professional development role is absent from both question 14 and 15 and question 6 (under Principal) about "who else in the school is vital to your success?".

\section{How influential do teacher-librarians think they are? Perceptions}

In "Building Influence for the School Librarian". Hartzell approaches his topic from the administration's viewpoint, while this survey approaches the topic from the point of view of the teacher-librarian. They were asked: Q1. How do you demonstrate influence? Q4. What are your spheres of influence outside the library? Q9. Are you the chair of any groups within the school? Q 11. What do you do to become personally visible in the school?

How do these teacher-librarians demonstrate influence? The answers to this question ranged from the importance of being on committees, which was perceived as 'having a voice' (A) to 'I ask the hard questions' and there is 'the perception that the teacher-librarian is knowledgeable' (B). An interesting and vital clue to B's influence was her comment that she 'plots a path to keep my agenda in the limelight'. She believes her 'support of staff' with technology and information skills is also a way of demonstrating influence. $\mathbf{C}$ added that she 'attends functions and events'. 'Attend' does not appear to be a term of influence. If she had 'organised' or 'initiated' activities, her influence would be perceived to be greater. D's responses were lengthy and detailed, using terms like 'future directions', 'modelling', describing herself as an 'outspoken member of committees'. She certainly practised Hartzell's urge to become engaged. Respondent $\mathbf{E}$ was aware of the language of influence by using words like 'proactive', 'working closely' (implying equal partnerships), 'on the ball', about her information literacy agenda. In contrast, $\mathbf{F}$ included personality elements in her response to question 1. She said she was 'liked by the students', 'respected by the staff, was 'asked advice by the teachers' and was 'invited to join committees'. $\mathbf{F}$ believed the above happened because she was 'organised, efficient and knowledgeable'. Hartzell (1994) proposes that knowing yourself, knowing your job, knowing your setting and knowing your constituents are important in maintaining influence. Interestingly $\mathbf{F}$ was the respondent who valued the MBTI as a tool.

What are their spheres of influence outside the library? Most respondents listed a series of successful activities in which they had been involved, ranging from mentoring programs and supporting the PEEL program (B), integrating technology into the curriculum (C), virtual classroom programs (E) to naming individuals who are influenced by them (D and F). There was a wide cross-section of spheres of influence: Computing, professional development, heads of department, curriculum co-ordinators, with only $\mathbf{D}$ including the 
principal in her sphere of influence. This resonates with the view that was expressed by the ETL 521 forum. The principal is important to the teacher-librarian but not necessarily the greatest influence on them.

What committees are teacher-librarians chairing? Four of the six teacher-librarians were chairing committees, which must give them considerable influence in those spheres at least. The range of committees was encouraging. Respondent $\mathbf{A}$ chaired 'Copyright and Archives', possibly not seen as a powerful committee by others within the school. It would have been worthwhile the have included in the survey a rating (1-10) question about the importance of their committees to the mission of the school. $\mathbf{C}$ chaired the 'Curriculum Resources Development Group', which includes some powerful members of the school community, including the principal. The 'Information Technology Committee' is chaired by respondent $\mathbf{D}$, and $\mathbf{F}$ is convenor of the school-wide 'Literature Festival Committee' (this committee includes parents and students).

How do these teacher-librarians become personally visible? There were some discrepancies in their responses to this question. Some of the respondents focussed on their professional or library visibility, which resulted in answers that were similar to their answers in question 1 about demonstrating influence. Respondents $\mathbf{A}$ and $\mathbf{C}$ included references to activities outside the library, which for $\mathbf{A}$ was the annual concert when the library staff put on 'an Act'. Respondent B considers herself 'outrageous', while $\mathbf{C}$ has been 'school musical director', 'editor of the school magazine' and 'speaks at staff meetings and curriculum days'. Like B, D focuses on appearance and personality, citing her liking for 'wearing loud colours'. 'Sending e-mails' and 'attending subject meetings' are considered by $\mathbf{E}$ to add up to personal visibility. Respondent $\mathbf{F}$ believes that being 'gregarious, warm, up-front and direct' is important. She also mentions 'talking to students and talking to everyone', along with 'going to happy hours' and 'attending assemblies' as important. $\mathbf{F}$ also places importance on appearance, citing 'dressing as an individual' as an element in her personal visibility. These teacher-librarians are indicating that their presence at school events, while 'dressed to be noticed' are strategies for increasing their influence in their schools. For many years the business community has been sending its staff to seminars on personal grooming, appearance and choice of 'power' colours, but it is not generally a topic that appears in library or education journals. Maybe we need to commission an expert to run a seminar or write an article for teachers and teacher-librarians on 'dressing for success' or 'developing an influential style'.

\section{What strategies do teacher-librarians use to build influence?}

Question 3 asks the participants about "....strategies they have put in place to ensure that there is a minimum of indifference towards information services or the library". Again, many of the responses were similar to the answers given in question 1 about demonstrating influence. However there were some different angles worth noting. Respondent $\mathbf{A}$ believes that a 'library presence on the Internet' and 'library skills classes', are strategies which 'result in a full library' and ensure minimum indifference. Of course, surveying the teaching staff can only test these assumptions. One of the respondents is 'working to overcome indifference', by building her own credibility, even if other library staff may lack it. Teacherlibrarian $\mathbf{C}$ appears to be more proactive when it comes to avoiding indifference. Her language changes from the passive, 'attends meetings', 'on committees' to the proactive language of influence. She 'established a global learning centre in the library' and 'initiates discussion about use of this space'. Respondent $\mathbf{D}$ is 'rebuilding professional respect' and 
'advocating far and wide'. F believes running 'efficient systems', having an inclusive student-centred service', and 'encouraging and supporting the library staff to be friendly and approachable' will ensure minimum indifference. All of these show a different approach and say more about the personality of the people being surveyed than they do about their professionalism.

Interestingly all six respondents answered question five positively and with great detail when asked if they 'had ever written an article for publication in a non-library journal, or spoken at a non-library conference?"

The following table gives an indication of the spread of areas where this group of teacher-librarians has either spoken at a conference or written a journal article.

\begin{tabular}{|l|l|l|l|l|}
\hline Computing & Subj. Assoc. & $\begin{array}{l}\text { Other } \\
\text { school/system }\end{array}$ & $\begin{array}{l}\text { Overseas } \\
\text { Conf/journa } \\
\text { ls }\end{array}$ & Universities \\
\hline $14+$ & $14+$ & $5+$ & 6 & 3 \\
\hline
\end{tabular}

It was encouraging to read that respondents $\mathbf{B}, \mathbf{C}, \mathbf{E}$ and $\mathbf{F}$ have all presented at conferences with other teachers. $\mathbf{C}$ and $\mathbf{E}$ have even presented with their Principals. $\mathbf{C}$ and $\mathbf{D}$ have written articles jointly with their principals. I believe that this data is not necessarily applicable to each respondent's current school.

The responses to question 7 "What tactics do you use to influence teachers?" are worth analysing. They appeared to fall into 3 groups: (a) modelling, (b) leading and (c) cooperating and providing. Respondent A modelled by 'showing the benefits of using the library', while D cited 'guiding', 'showing', 'telling', 'doing' as strategies she used. E also models as she 'demonstrates educational benefits for students'. B and $\mathbf{F}$ both appeared to prefer leading strategies, using the language of influence. $\mathbf{B}$ said she 'lead by example'. $\mathbf{F}$ used the terms 'surprising them with new initiatives' and 'introduces', suggesting a proactive approach to influence. $\mathbf{F}$ also used co-operating and providing strategies 'working through the principal and the senior committee', as did $\mathbf{C}$, who 'works alongside teachers'.

When looking at influence in schools, the parent body must never be overlooked. Question 13 asked the participants " what have you done to capture the support of parents?" All of the respondents were active in this area. They speak at parent meetings, write for their newsletters, organise 'friends of the library' (A, B, C and F). Respondents A, B, E and F have initiated activities for parents in the evenings. This group of teacher-librarians has acknowledged the importance of parents, but they do not appear to have used the depth of influence that is potentially possibly. Hartzell (1994) includes several pages of suggestions of ways teacher-librarians can capture the support of parents, which were not mentioned by the respondents.

There are three possible reasons that could explain the lack of innovation in gaining the support of parents amongst this particular group of teacher-librarians: (1) the cultural differences between schools in the United States and Australia;(2) the surveyed group is primarily from the independent system which has different demographics; (3) or simply, parents are currently being overlooked as potential sources of influence by teacher-librarians. 


\section{How do teacher-librarians see their relationship with their Principal?}

Many writers have looked at the significance of the Principal's relationship with the teacher-librarian. Haycock (1981) suggested that without Principal support teacher-librarians were unlikely to get to first base. Henri (1988) believed that "teacher-librarians thrive upon the leadership of energetic, supportive, visionary administrators". Hay and Henri in 1995 continued this theme, going so far as to suggest that the teacher-librarian should share the 'world view' of the Principal and have broad based support within the school.

What is the view amongst the surveyed group of teacher-librarians?

Of the 6 people surveyed, only three respondents believed that the Principal was aware of the nature of their job. Those who answered 'Yes', described the Principal as 'sending them articles about good libraries', so he must know what I do (A). C who has presented at a conference with her Principal believes he knows what she does. Recent conversations that $\mathbf{E}$ has had with her Principal indicate that 'she is now more aware'.

The three respondents who answered 'No', include the two teacher-librarians who have been in their schools under 2 years. Both indicated that they were being proactive in informing the Principal. F sends him copies of library meeting minutes and articles she writes. He gives feedback, so she knows he reads them.

All but one of the teacher-librarians feels that they get positive feedback from their Principals. They give written and verbal support; they listen to ideas and 'seem to enjoy discussions'. They 'showcase the library to visitors' and are 'generous with positive comments'. This is clearly not a group of teacher-librarians without influence with their Principal. However, in question 14 and 15, in the second part of the survey, A, C, D, E, F all listed the Principal as one of five people who influence them in their schools, but only $\mathbf{D}$ indicated that she had any influence over the Principal in answer to Question 15.

It would have been interesting to ask the participants if they agreed with Hay and Henri's (1995) proposition that teacher-librarians thrive under visionary and supportive administrators.

Only one of the six respondents had scheduled meetings with her Principal, but all indicated that there was regular official and unofficial contact in the staff room, at recess, by e-mail and that meetings were arranged as required. Most of the teacher-librarians, when responding to the question, "How does the Principal support the library?" cited budgets, staffing, professional development opportunities, speaking positively about the library and encouragement. F went a step further, noting more personal support from the Principal by mentioning that there was 'autonomy, trust, faith, respect'. Hay and Henri's initial findings from their 1995 study, found that Principals "rely on the professional judgement of the teacher-librarian, so long as the teacher-librarian demonstrates that trust is warranted". If the survey had phrased the question more personally there may have been more enlightening responses.

What strategies then do these teacher-librarians use to get Principal support. They present solutions, not problems (A, F); use correct channels, try to influence the real decision-makers (B); focus on benefits for students (C); support arguments with examples and statistics $(\mathbf{C}, \mathbf{F})$; have constant dialogue (D); share initiatives (E, F); give him articles about education, learning and libraries (F). 


\section{Do teacher-librarians participate in politics?}

One of the surprising outcomes from the survey was the lack of awareness or acknowledgement that politics is part of building influence for teacher-librarians. In question 6 the participants were asked "Do you take part in internal school politics?" They were also asked if they were comfortable with this? Three said 'Yes' ( B, D, F), three answered 'No' $(\mathbf{A}, \mathbf{C}, \mathbf{E})$. The 'No' respondents said 'I am politically naïve', 'I avoid it', 'No, but I am well informed'. The 'Yes' respondents added 'to increase opportunities for collaboration' (D), 'influence is enhanced if aware of politics' and 'it is most important to find out who to try and influence $(\mathbf{F})$.

Hartzell (1994) reminds us that every organisation is political and cites Bellman (1992), who counsels us to acknowledge the reality of politics and to know that we are part of the process. Even if we do not see our actions as political, others might.

\section{Shortcomings of Survey}

- It appeared from many of the answers to the survey questions that the respondents were guessing. What were being tested were the perceptions of the teacher-librarians. Not one of the respondents mentioned that they had undertaken any sort of survey of user needs. They may have overlooked this in their answers, so the survey should have asked this question at the outset.

- As the surveys came in and the responses were collated, it was clear that there were not enough personal questions to get an objective picture of the personalities of the teacherlibrarians. It would have been interesting to ask them "How would the students/Principal describe you?" As only two respondents had undertaken a Myers Briggs analysis, this question was unable to be adequately pursued.

- Colleagues in the respondents' schools could have been contacted and questioned on how ' $\mathrm{X}$ ' demonstrates influence. Unfortunately this was not possible for this project.

- Another question that should have been included was "Do you want to be influential in your school. If so, Why? "There was the presumption in the questions that influence was desirable. However, the responses to question 8, "what would be different if you had more influence?" were diffident. It was surprising to see a lack of interest in this possibility. $\mathbf{C}$ would have 'more impact on teaching, learning and curriculum planning'. D said 'everything would be different'. $\mathbf{E}$ indicated a 'voice on information literacy would be on all the curriculum documents'. F would be 'part of the senior executive' and 'we would be an information literate school community'

\section{Summary}

Langford (2000) sees influence as being about credibility and about understanding and using the power of heuristics. The teacher-librarians in the survey are certainly aware of the importance of credibility, but as a group are not using the language of Hartzell's heuristics of influential people; that is likeability, expertise, sensitivity, a controlled ego and focussed energy and effort.

Most of the respondents indicated that they were valued by the Principal, by teachers and students and indeed by the parents. Their self-esteem, their credibility and their expertise 
Boyd

were all intact. People want to be involved with a teacher-librarian with a high profile. Therefore their potential for influence was huge and perhaps under-utilised.

"The most influential teacher-librarians make teachers look brilliant, but who makes the teacher-librarian look brilliant" (Personal communication, James Henri to Suzette Boyd October, 2000)

If an outcome of a survey of this type was that teacher-librarians gave more thought to being influential, perhaps they will eventually become brilliant. 
肴

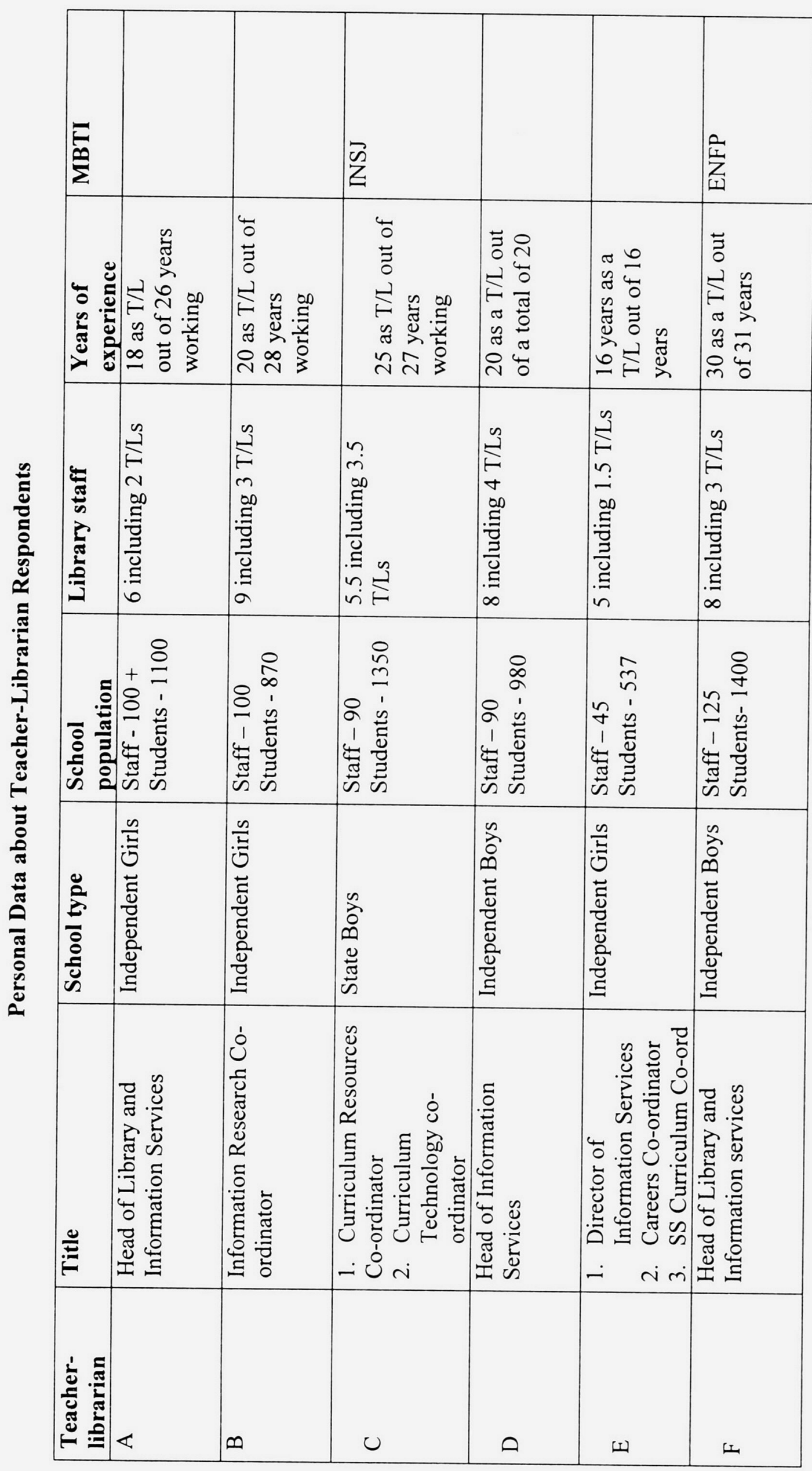

